\title{
Empirical Research on MIS Teaching of Non-professional Information Management
}

\author{
Fang Lu \\ School of Finance and Economics \\ Hunan University \\ Zhuzhou, China \\ Lufang31@126.com
}

\author{
Ming Yang \\ School of Finance and Economics \\ Hunan University \\ Zhuzhou, China \\ 535502836@qq.com
}

\begin{abstract}
Recently, many universities open MIS (Management Information System) courses in non-professional information management. How to improve teaching quality on MIS course of non-professional information management has drawn more and more colleges' attention. The teaching quality and influence factors on study performance on MIS course of non-professional information management are studied through researching on the students in the grade 2010 in school of finance and economics. Results show different teaching methods should be carried out in MIS course of non-professional information management.
\end{abstract}

Keywords-non-professional information management; management information systems; teaching quality; factor analysis

\section{INTRODUCTION}

Management Information System is between management science, information science, system science, and modern communications technology and computer science of the academic knowledge, with fringe, comprehensive and systematic other features. In many organizations and social and economic activities of the Information Management, currently, it has been widely used and plays an increasingly important role [1]. Therefore, all colleges and universities in succession in Economics and Management School began to open MIS professional courses. However, as the course involves relatively broad professional knowledge, requiring students to have some mathematics, computer science and engineering technology knowledge, professional students in each subject knowledge structure varies. Therefore, there are many issues that need improvement in non-information management professionals MIS course teaching process of major universities [2] [3] [4].

As economic management professional core courses and Information Management basic course, MIS professional teaching course for different purposes is different [5]. Thus, for non-professional information management MIS teaching, we need against its non-professional information management features in the basics and disciplinary backgrounds requirements, teaching content system settings, practical aspects of the arrangements and the student evaluation system with the Information Management Professional teaching of MIS differ [7]. Comparative Information Management majors and non-Information Management characteristics, it is significant for our country to seize the MIS course essence, for non-information management individualized, develop a reasonable non-professional information management MIS course training objectives and teaching implementation plan, deepen non-professional information management MIS course teaching reform. They cultivate significance on China non-professional information management.

In view of this, the paper, aiming at opened MIS course for each different majors, does teaching quality MIS survey data analysis .Through the survey results, draws the corresponding conclusions, inquiries MIS course in the non-professional information management teaching programs, triggers non-professional information management students enthusiasm and increases students' MIS courses learning performance in non-professional information management.

\section{RESEARCH METHORD AND DATA ANALYSIS}

\section{A. Questionnaire Design}

In these paper questionnaires, we carry on the investigation to the various majors who have already completed the MIS course in school of Finance and Economics of Hunan University of Technology. This questionnaire is divided into the following sections: (1) College student primary information (PI);(2) Students' level of related knowledge investigation (RK);(3)Theoretical classroom teaching ability (TA);(4)Teachers' practical teaching ability(PA);(5)Students' learning performance survey $(\mathrm{P})$.

Students' level of related knowledge is main survey of the professional courses before students in learning for their own MIS possess knowledge of MIS course satisfaction. Theoretical classroom teaching ability is mainly investigate students' acceptance of the content of classroom teaching, the extent of the specific methods for teaching satisfaction and case selection in case teaching aspects of the evaluation. Practical teaching ability teaching practice preparation main survey and the specific implementation; study is to investigate the performance of primary students in various professional courses after completion of MIS, theoretical knowledge and practical ability to apply whether the expected learning outcomes. These parts of the problem is mainly based on multiple choice, in addition to the first part of the survey of college students, the other four parts by using Likert scale, on every issue, and designs according to the actual situation and effect of 5 grades, namely the $1=\mathrm{E}$ options, $2=\mathrm{D}$ options $3=\mathrm{C}$ options $4=\mathrm{B}$ options $5=\mathrm{A}$ options.

\section{B. Sampling Situation}

This survey questionnaire a total of 450 , recycled 386,369 people effectively, the effective rate was $82.44 \%$. Among them, 
the science students 159 people, accounting for $43.4 \%$, liberal arts students 210 people, accounting for 56.6\%; Information Management Professional 73 people, accounting for 19.68\%; Accounting profession 117 people, accounting for $31.81 \%$; Financial Management 77 people, accounting 20.20.75\%; International Trade 102 people, accounting for $27.76 \%$, non-professional fuses or all students are more evenly distributed.

\section{ANALYSIS}

\section{A. Factor Analysis}

Factor analysis on part of TA and PA data by SPSS, posed by the teaching ability variable correlation matrix for factor analysis to examine the appropriateness of results, information capacity of KMO sampling adequacy sample measured value 0.831; Bartlett test of sphericity show that, $\chi^{2}$ Significant statistics Possibility is 0.000 , less than 0.01 . The above results indicate that the selected indicator data is suitable for factor analysis .The factor analysis uses principal components analysis and variance maximization orthogonal rotation method, the factors whose characteristic value are greater than 1 are extracted as the main factor. Table I shows the results of factor analysis teaching ability.

\section{TABLE I. TEACHING ABILTY OT FACTOR ANALYSIS}

\begin{tabular}{|c|c|c|}
\hline \multirow{2}{*}{ Study variables to measure the questions } & \multicolumn{2}{|c|}{ Factor loadings } \\
\hline & Factor 1 & Factor 2 \\
\hline TA 2Course content readiness & 0.579 & \\
\hline $\begin{array}{l}\text { TA3Multimedia teaching dictation } \\
\text { capabilities Knowledge }\end{array}$ & 0.655 & \\
\hline $\begin{array}{l}\text { TA4Multimedia teaching courseware } \\
\text { design capabilities }\end{array}$ & 0.678 & \\
\hline $\begin{array}{l}\text { TA5For quantitative evaluation model to } \\
\text { explain the ability of cases }\end{array}$ & 0.750 & $<0.5$ \\
\hline $\begin{array}{l}\text { TA6For logical database class strong ability } \\
\text { to explain the type of cases }\end{array}$ & 0.604 & \\
\hline $\begin{array}{l}\text { PA1Arrangements experimental design } \\
\text { capability }\end{array}$ & & 0.673 \\
\hline $\begin{array}{l}\text { PA2Ability to control experimental design } \\
\text { standards }\end{array}$ & & 0.837 \\
\hline $\begin{array}{l}\text { PA4Experiment Equipment update } \\
\text { capability }\end{array}$ & $<0.5$ & 0.619 \\
\hline $\begin{array}{l}\text { PA5In-depth business practice teaching } \\
\text { ability }\end{array}$ & & 0.734 \\
\hline Characteristic value & 3.345 & 1.340 \\
\hline Cumulative variance contribution rate $(\%)$ & 37.163 & 52.046 \\
\hline Factor named & $\begin{array}{l}\text { Theoretical } \\
\text { classroom } \\
\text { teaching }\end{array}$ & $\begin{array}{c}\text { Practical } \\
\text { application } \\
\text { of teaching } \\
\text { ability }\end{array}$ \\
\hline
\end{tabular}

Factor analysis on part of learning performance $(\mathrm{P})$ data by SPSS, posed by the learning performance variables on the correlation matrix to examine the appropriateness of factor analysis showed, learning Performance of KMO sampling adequacy sample measured value 0.849; Bartlett test of sphericity show that, $\chi^{2}$ Significant statistics Possibility is 0.000 , less than 0.01 . The above results indicate that the selected indicator data is suitable for factor analysis. Factor analysis extracted two factors were named theoretical knowledge and practical ability. Measurement of the questions of each factor loadings are above 0.5 , it indicates a good degree of convergence, and two factors cumulative variance contribution rate of $59.822 \%$, Cronbach's Alpha coefficient is 0.863 , reliability is better. Description learning performance measurement is more effective. Table II shows the results of factor analysis learning performance.

Factor analysis on some of the related professional knowledge (RK)data by SPSS, level of knowledge by the student-related variables on the correlation matrix composed of factor analysis to examine the appropriateness of results, Learning Performance KMO sampling adequacy of the sample measured value of 0.853 ; Bartlett test of sphericity show that, $\chi^{2}$ Significant statistics Possibility is 0.000 , less than 0.01 . The above results indicate that, the selected indicator data is suitable for factor analysis. Table III shows the level of students' knowledge of factor analysis.

TABLE II. LEARNING PERFORMANCE OT FACTOR ANALYSIS

\begin{tabular}{|c|c|c|}
\hline \multirow[t]{2}{*}{ Study variables to measure the questions } & \multicolumn{2}{|c|}{ Factor loadings } \\
\hline & Factor 1 & Factor 2 \\
\hline $\begin{array}{l}\text { P1Teaching the theory of conceptual } \\
\text { understanding of the course }\end{array}$ & 0.733 & \multirow{3}{*}{$<0.5$} \\
\hline $\begin{array}{l}\text { P2Theoretical teaching on the impact of } \\
\text { system requirements analysis }\end{array}$ & 0.763 & \\
\hline $\begin{array}{l}\text { P3Feasibility Analysis on theoretical } \\
\text { teaching ability of the system }\end{array}$ & 0.720 & \\
\hline $\begin{array}{l}\text { P4Practical teaching ability of the graphics } \\
\text { rendering }\end{array}$ & \multirow{3}{*}{$<0.5$} & 0.746 \\
\hline $\begin{array}{l}\text { P5Practical teaching ability of the system } \\
\text { design }\end{array}$ & & 0.865 \\
\hline $\begin{array}{l}\text { P6Practical teaching ability of the system } \\
\text { implementation }\end{array}$ & & 0.805 \\
\hline Characteristic value & 3.589 & 1.846 \\
\hline Cumulative variance contribution rate $(\%)$ & 34.823 & 59.822 \\
\hline Factor named & $\begin{array}{l}\text { Theoretical } \\
\text { classroom } \\
\text { teaching }\end{array}$ & $\begin{array}{l}\text { Practical } \\
\text { application } \\
\text { of } \\
\text { teaching } \\
\text { ability }\end{array}$ \\
\hline
\end{tabular}

TABLE III. STUDENTS LEVEL OF RELATED KNOWLEDGE FACTOR ANALYSIS

\begin{tabular}{|l|c|}
\hline \multicolumn{1}{|c|}{ Study variables to measure the questions } & Factor loadings \\
\cline { 2 - 2 } & Factor 1 \\
\hline RK1Subject-related knowledge management & 0.658 \\
RK 2Systems engineering disciplines related & 0.715 \\
knowledge level & 0.639 \\
RK3Computer science-related knowledge & 0.739 \\
RK 4Management information systems for \\
the understanding of cutting-edge science \\
$\begin{array}{l}\text { RK 5Management Information Systems for } \\
\text { the attention of cutting-edge science }\end{array}$ \\
\hline Characteristic value & 0.624 \\
\hline Cumulative variance contribution rate (\%) & 1.873 \\
\hline \multicolumn{1}{|c}{ Factor named } & 61.778 \\
\hline
\end{tabular}

\section{B. Correlation Analysis}

In the basis of factor analysis, correlation analysis for each factor, in order to explore the relationship between the various factors, lay the foundation for the regression analysis. The results are shown in Table IV.

From the correlation analysis ,the teacher's theoretical classroom teaching ability, practical application of teaching ability are highly related to learning performance of theoretical 
knowledge and practical ability in 0.05 level. It explains that Classroom teaching and practice teaching to the study of management information system course performance has a positive impact. However, Students related professional knowledge level is also highly related to learning Performance in 0.05 levels. It illustrates that learning performance is also affected by the students related professional knowledge level.

TABLE IV. CORRLATION ANALYSYS OF EACH FACTOR

\begin{tabular}{|c|c|c|c|c|c|c|}
\hline & & 1 & 2 & 3 & 4 & 5 \\
\hline 1 & $\begin{array}{c}\text { Theoretical } \\
\text { classroom teaching } \\
\text { ability }\end{array}$ & 1 & & & & \\
\hline 2 & $\begin{array}{c}\text { Practical } \\
\text { application of } \\
\text { teaching ability }\end{array}$ & 0.493 & 1 & & & \\
\hline 3 & $\begin{array}{c}\text { Relevant level of } \\
\text { expertise }\end{array}$ & 0.197 & 0.523 & 1 & & \\
\hline 4 & $\begin{array}{l}\text { Theoretical } \\
\text { knowledge }\end{array}$ & $0.819 *$ & $0.725 *$ & $0.859 *$ & 1 & \\
\hline 5 & Practical ability & $0.741 *$ & $0.596 *$ & $0.676 *$ & 0.328 & 1 \\
\hline
\end{tabular}

\section{Regression Analysis}

Related to regression analysis, it can be seen that the relationship between the factors in the tightness, regression analysis can further illustrate the causal relationship between the various factors. This part, regression analysis was carried out on the causality of each variable theoretical of classroom teaching ability, relevant level of expertise and learning performance. Respectively, the two factors of teaching ability and students related professional knowledge level of a factor as the independent variable, to study the performance of two factors were used as the dependent variable principal component regression analysis.

- Regression analysis of theoretical knowledge learning performance

Theoression knowledge factors as the dependent variable, theoretical classroom teaching ability, teaching ability of practical application, the student's own characteristics three factors as independent variables, principal component regression model fitting are shown in Table V.

TABLE V. MODEL SUMMARY

\begin{tabular}{|c|c|c|c|c|}
\hline Model & $\mathrm{R}$ & $\mathrm{R}^{2}$ & Adjusted $^{2}$ & Standard error of estimate \\
\hline 1 & $0.824 \mathrm{a}$ & 0.679 & 0.668 & 0.144 \\
\hline
\end{tabular}

\begin{tabular}{|c|c|c|c|c|}
\hline & & & & Anoval \\
\hline Model & Squares & mean square & $\mathrm{F}$ & Sig \\
\hline Regression & 4.531 & 1.625 & 36.788 & $0.000 \mathrm{a}$ \\
\hline Residuals & 0.193 & 0.039 & & \\
\hline Total & 4.724 & & & \\
\hline
\end{tabular}

By above knowable, principle components regression model fits better overall $(\mathrm{R} 2=0.668)$. Analysis of variance table shows the results of a statistically significant $(\mathrm{P}=0.000)$. The principal component regression parameter estimates and hypothesis test results in Table VI.
TABLE VI. COEFFCIENTS A

\begin{tabular}{|c|c|c|c|c|c|}
\hline Model & B & $\begin{array}{c}\text { Standard } \\
\text { error }\end{array}$ & $\begin{array}{c}\text { Standard } \\
\text { factor beta }\end{array}$ & $\mathrm{t}$ & Sig \\
\hline Constant & 0.187 & 0.055 & & 13.268 & 0.000 \\
\hline $\begin{array}{c}\text { Theoretical } \\
\text { classroom } \\
\text { teaching } \\
\left.\text { ability(f } f_{1}\right)\end{array}$ & 0.265 & 0.055 & 0.293 & 6.452 & 0.000 \\
\hline $\begin{array}{c}\text { Practical } \\
\text { application } \\
\text { of teaching } \\
\left.\text { ability(f } f_{2}\right)\end{array}$ & 0.137 & 0.055 & 0.187 & 5.028 & 0.006 \\
\hline $\begin{array}{c}\text { Relevant } \\
\text { level of } \\
\text { expertise }\left(\mathrm{f}_{3}\right)\end{array}$ & 0.186 & 0.055 & 0.226 & 5.858 & 0.005 \\
\hline
\end{tabular}

From the above table shows, $\beta_{0}, \beta_{1}, \beta_{2}$ are statistical significance $(\mathrm{P}=0.000 、 0.000 、 0.006 、 0.005)$. That is, from classroom teaching ability factor $f_{1}$, practical application of teaching ability factor $f_{2}$, the level of expertise relevant to students theoretical knowledge factor $f_{3}$ have effect on the role of learning performance variables $\mathrm{P} 1$, the linear regression equation (1):

$$
P_{1}=0.187+0.265 f_{1}+0.137 f_{2}+0.186 f_{3}
$$

By a series of analysis and formula can be seen above, teaching ability of two student-related factors and the level of expertise of a factor on the theoretical knowledge of the explanatory power of learning performance $\mathrm{R} 2=0.679$, reaching $67.9 \%$. Theoretial classroom teaching ability makes large contribution to Theoretical knowledge learning performance changes. It shows that theoretical teaching of theoretical knowledge has a direct impact on learning performance.

- Practical ability of learning performance regression analysis

Practical ability factor as the dependent variable, theoretical classroom teaching ability, practical application of teaching ability, level of expertise relevant to student's three factors as independent variables, principal component regression model fitting are shown in Table VII.

TABLE VII. MODEL SUMMARY

\begin{tabular}{|c|c|c|c|c|c|}
\hline Model & $\mathrm{R}$ & $\mathrm{R}^{2}$ & Adjusted $\mathrm{R}^{2}$ & Standard error of estimate \\
\hline 1 & $0.916 \mathrm{a}$ & 0.839 & 0.804 & \multicolumn{2}{|c|}{0.186} \\
\hline \multicolumn{7}{|c|}{ Anovab } \\
\hline Model & Squares & mean square & $\mathrm{F}$ & Sig \\
\hline Regression & 6.317 & 1.586 & 42.058 & $0.000 \mathrm{a}$ \\
\hline Residuals & 0.177 & 0.067 & & \\
\hline Total & 6.494 & & & \\
\hline
\end{tabular}

By above knowable, principal component regression model fits better overall $(\mathrm{R} 2=0.668)$. Analysis of variance table shows the results of a statistically significant $(\mathrm{p}=0.000)$. The principal component regression parameter estimates and hypothesis test in Table VIII. 
TABLE VIII. COEFFICIENTS A

\begin{tabular}{|c|c|c|c|c|c|}
\hline Model & B & $\begin{array}{c}\text { Standard } \\
\text { error }\end{array}$ & $\begin{array}{c}\text { Standard } \\
\text { factor beta }\end{array}$ & $\mathrm{t}$ & $\mathrm{Sig}$ \\
\hline Constant & 0.146 & 0.062 & & 24.582 & 0.000 \\
\hline $\begin{array}{c}\text { Theoretical } \\
\text { classroom } \\
\text { teaching } \\
\left.\text { ability( } \mathrm{f}_{1}\right)\end{array}$ & 0.212 & 0.063 & 0.351 & 4.371 & 0.001 \\
\hline $\begin{array}{c}\text { Practical } \\
\text { application of } \\
\text { teaching } \\
\left.\text { ability( } \mathrm{f}_{2}\right)\end{array}$ & 0.284 & 0.063 & 0.427 & 6.253 & 0.005 \\
\hline $\begin{array}{c}\text { Relevant } \\
\text { level of } \\
\text { expertise }\left(\mathrm{f}_{3}\right)\end{array}$ & 0.176 & 0.063 & 0.229 & 3.339 & 0.000 \\
\hline
\end{tabular}

From the above table shows, $\beta_{3}, \beta_{4}, \beta_{5}$ are statistical significance $(\mathrm{P}=0.000 、 0.001 、 0.005 、 0.000)$, that is, from classroom teaching ability factor $f_{1}$, practical application of teaching ability factor $f_{2}$, the level of expertise relevant to students theoretical knowledge factor $f_{3}$ have effect on the role of learning performance variables $P_{2}$, the linear regression equation (2):

$$
P_{2}=0.146+0.212 f_{1}+0.284 f_{2}+0.176 f_{3}
$$

By a series of analysis and formula can be seen above, teaching ability of two student-related factors and the level of expertise of a factor on the practical ability of the explanatory power of learning performance R2 $=0.839$,reaching $83.9 \%$. And that, in the three factors, Practical application of teaching ability makes large contribution to Theoretical knowledge learning performance changes. It shows that Practical application of teaching has a direct impact on Practical ability of learning performance.

Based on the above analysis we can see, The learning performance is mainly affected by the teachers' teaching ability, Theoretical teaching and practical application of teaching have a significant direct positive effect on learning to improve the level of theoretical knowledge and practical ability. This fully shows that teachers in the MIS curriculum have leading role. Secondly, the level of expertise relevant to students is also to some extent affected the students' learning performance.

\section{SUGGESTIONS}

This thesis analyses students level of related knowledge, theoretical classroom teaching ability, practical teaching ability and students learning performance and so on depending on the questionnaire survey of the students who have completed the MIS courses in school of finance and economics in Hunan University of Technology. According to the analysis result, and put forward the following Suggestions:

A. Focus on the relevant professional knowledge and the introduction of cutting-edge technology

In order to master the MIS courses students should be offered more relevant knowledge properly, reinforced the understanding of the cutting-edge technology, teachers should make the comprehension of classes easier for students improve the efficiency of learning indirectly. Due to there is great gap between students' former major and the knowledge giver now, some would not be interested in MIS, so base on the cutting-edge technology, it is the teachers duty to select content according to various professional characteristics.

\section{B. Teaching theoretical knowledge by taking the} characteristics of students' own majors

Because non-professional information management students have their own professional features, teachers have to emphasis on it so as to improve the performance of MIS course teaching. Teaching students in accordance of their aptitude improving their interests, focusing on this point appropriately during theoretical teaching are keys to these students.

\section{Enhance the comprehension by combining case \\ background}

Aiming at the problem of case teaching performance is not high; teachers have to collect cases that fit each non-majors student by a lot of time. When choosing case, teachers should make sure that every case chosen is not too hard. Before they read it assigned some papers to consult, it can be partly removed in the coming procedures that teaching issues because of the non-understanding of case.

To sum up, it is recommended that the non-professional information management should have their own training program so as to improve their attitude to MIS guide and strengthen their understanding and practical application ability actively.

\section{ACKNOWLEDGMENT}

This paper is supported by Hunan University of Technology Foundation (2012C38, JG1304)

\section{REFERENCES}

[1] Liu Chaohua. Characteristic Teaching and Practice of "Management Information System " for Marketing Major [J]. Science and technology consulting, 2011, 4 (1): 191-192.

[2] Lai Keqin and Zhang Jinsong. Management Information Systems course to lead the project and task-driven practice teaching model [J]. Chinese science and innovation Tribune, 2012, 31 (6):230-231.

[3] GU Jiguang. Teaching Research on Management Information System Course for Management Professional [J]. Chinese management information, 2012, 15 (11):96-97.

[4] Wang Xin, Zhang Yi and Ding Tao. Teaching Reformation and Practice Research on Management Information System Course [J]. Northeast Electric Power University, 2012, 32 (5):56-58.

[5] Dong Chengliang. Industrial engineering-oriented management information systems courses teaching $[\mathrm{J}]$. Chinese management information, 2012, 15 (3):91-92.

[6] Xu Shengju and Xu Shenghua. Teaching Reform of Management specialty Management Information Systems course [J]. Library Science, 2012, 1 (1):7-10.

[7] Yan Haoyun, Zhang Xiaohong and Xu Shengliang. Teaching Research Applied Undergraduate Management Information Systems Management Major [J]. Chinese management information, 2013, 16 (4):53-54. 